Journal of Al - Azhar University Engineering Sector

Vol. 14, No. 53, October, 2019, 1534-1542

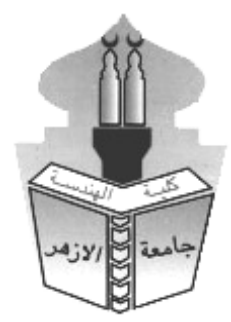

\title{
NATURAL VENTILATION ASSESSMENT IN EDUCATIONAL BUILDINGS , MARIN COUNTRY DAY SCHOOL- NEW BUILDING, CORTE MADERA, CA
}

\author{
*Hana Awad, Alaa Sarhan and Rania Abd El Gelil \\ Architecture and Urban Design, Arab Academy for Science, Technology and Maritime \\ Transport, College of Engineering and Technology, Alexandria, Egypt. \\ *Corresponding author Email: hanaawad 92@ hotmail.com
}

\begin{abstract}
Education is one of the major sectors of national development. People devote their time in educational buildings which must be constructed to shelter inhabitants against any unfavorable outside conditions and to offer them a healthy, comfortable and sustainable environment. Learning and Studying is a very concentrated and complex procedure which requires a lot of mental work. Thus, it requires an area with a good quality of air flow and natural ventilation to thermally satisfy inhabitants which can possibly increase their productivity. Currently, many educational buildings have some problems with poor natural ventilation and indoor air quality. When it comes to design of educational buildings architects most commonly rely on fulfilling the functional requirements. However, for a sustainable educational environment, natural ventilation design measures must be taken into account. A healthy and comfortable indoor condition heavily depend on the design and operation of the natural ventilation system which comply on actual standards. Therefore, this paper will analyze natural ventilation design measures in Mediterranean climatic region which have an impact on airflow on a private educational building in Corte Madera, California .
\end{abstract}

KEYWORDS :Natural Ventilation ,Educational buildings, Healthy environment, Mediterranean climate. National Development

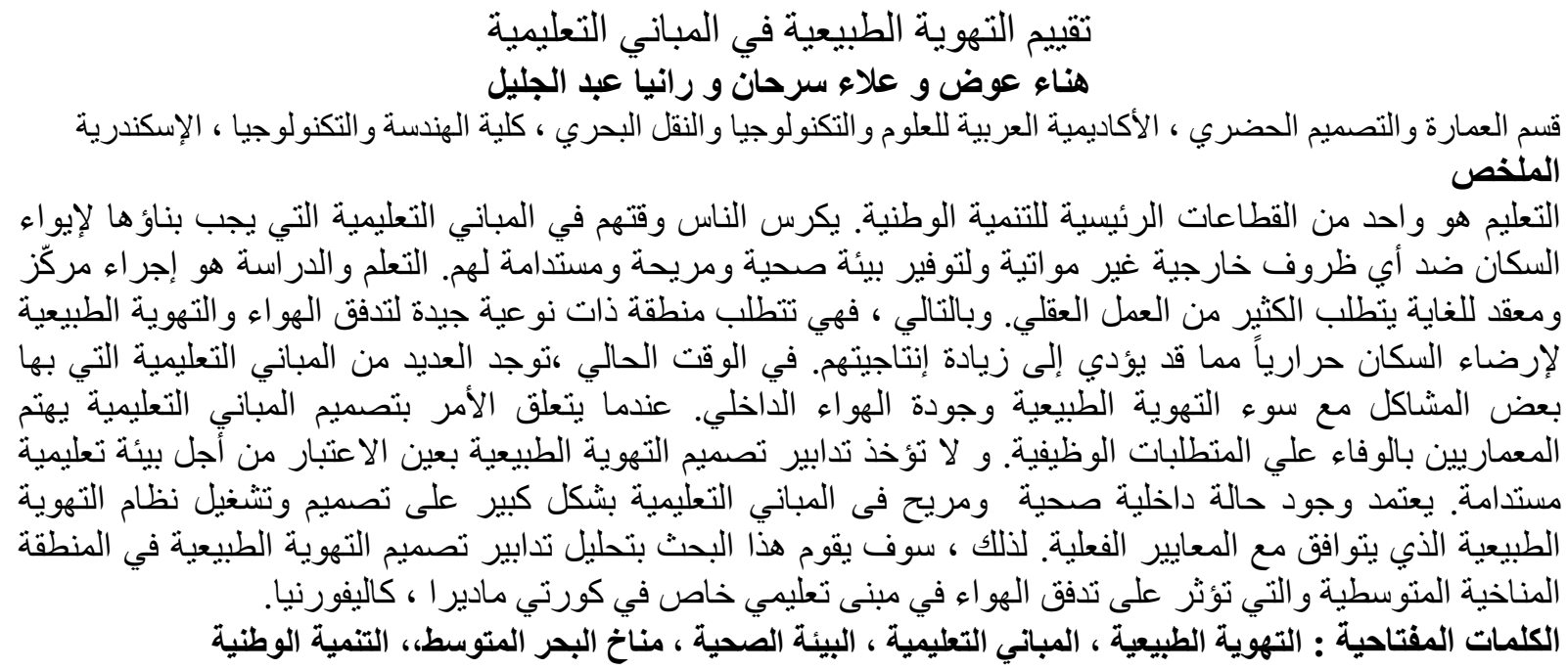

\section{INTRODUCTION}

Thermal comfort and natural ventilation overlay are the two main concepts to attain adequate indoor sustainable environment in educational buildings (Haddad, 2016). The use of indoor 
sustainable educational environment by centering on planning with passive techniques for natural ventilation is the main the main study of the paper, which in turn will maximizes the potential of offering thermal comfort for occupants using natural ventilation strategies $(\mathrm{Wu}$, Ziqi, 2011).Natural ventilation design requires knowledge of the mechanism of air flow through buildings and of factors which have an impact on air flow patterns indoors. In this research will outline and deliberate the essential considerations to design with natural ventilation. In addition, the design measures are comprehensively will be classified and the effect of their parameters on natural ventilation that identified by other researchers is critically reviewed. This paper evaluates the natural ventilation potential in an example in Marin Country Day School- new buildings, Corte Madera, CA. The example is analyzed study complex for comfort ventilation strategies through single sided ventilation and ventilation design measures .

\section{Designing with Natural Ventilation}

Designing with natural ventilation consists of two assessments which are initial assessment and design consideration assessment that are concerned with conceptual process and architecture design consideration process respectively. Conceptual process is categorized to Natural driving forces, ventilation strategies and ventilation principles (KAMORU, 2010) . While the paper will focus on architecture design consideration that is concerned with architectural aspects which is sorted to two main factors which are the site characteristics and building characteristics.

\section{Natural driving forces}

The study will focus on single sided ventilation which is a one-sided control technique where ventilation opening(s) is only on one side of the room or many openings on the same façade.

$$
\begin{aligned}
& \text { Ventilation due to wind } \\
& Q=0.025 A V \\
& \text { where } A \text { is the opening surface and } \\
& V \text { is the wind velocity. }
\end{aligned}
$$

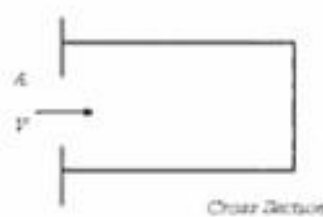

Figure 1 Formulae for single-sided ventilation equation (1) (Francis Allard, Mat Santamouris, 2002) The air change rate $(\mathrm{ACH})$ which is the defined as the measure of how many times the air within a defined space is replaced per hour. Inhabitants can have a ach starting from 5 but won't feel thermally satisfied .For an ideal air quality and to achieve thermal satisfaction, the room should have between 40 to 50 air change rate while for a good air quality interiorly 15ACH, (Gomaa B. , 2015).

Air change rate equation, $\mathrm{Ach}=\times 3600 /$

\section{Architectural Design Considerations}

Designing with natural ventilation reviews the architectural design considerations and their parameters influencing air movement in and around the buildings. Architectural Design Consideration are classified into categories the macro-level, the micro-level which are linked to site and building characteristics respectively. The following summary is applicable for moderate climate only .

\section{Macro level:}

The macro level design which is linked with site characteristics and how to consider them when designing for natural ventilation are summarized below in figure 2. Site landform, heat sinks urban form and streets design are the site characterises that affect natural ventilation in a precise mode (Bhatia, 2012).

\section{Macro level:}

Designing a building for optimum natural ventilation means taking in consideration several factors related to the airflow movement around and within the building. The factors of building design related to air movement can be assembled based on their relation to (Heiselberg, Per Kvols, 2006) . 


\section{Marin Country Day School- new buildings, Corte Madera, CA}

Marin Country Day School is an independent coeducational day school serving grades K-8 located in Corte Madera, California. The student body is made up of about 580 students. The campus area is 35 acres (140,000 m2); 34 classrooms, science laboratories, computer laboratory, music and art Buildings, library, performing arts auditorium, Marine Science dock, gymnasium, P.E. pavilion, multipurpose room, makers' lab, MCDS/PM and ASAP Headquarters. Throughout the project, sustainable features are fully combined with the architecture to deliver a representative teaching tool and significant measurable benefits. It has been awarded LEED ${ }^{\circledR}$ Platinum certified project certification from the U.S. Green Building Council as the building consumes less energy than it produces (EHDD, 2017)

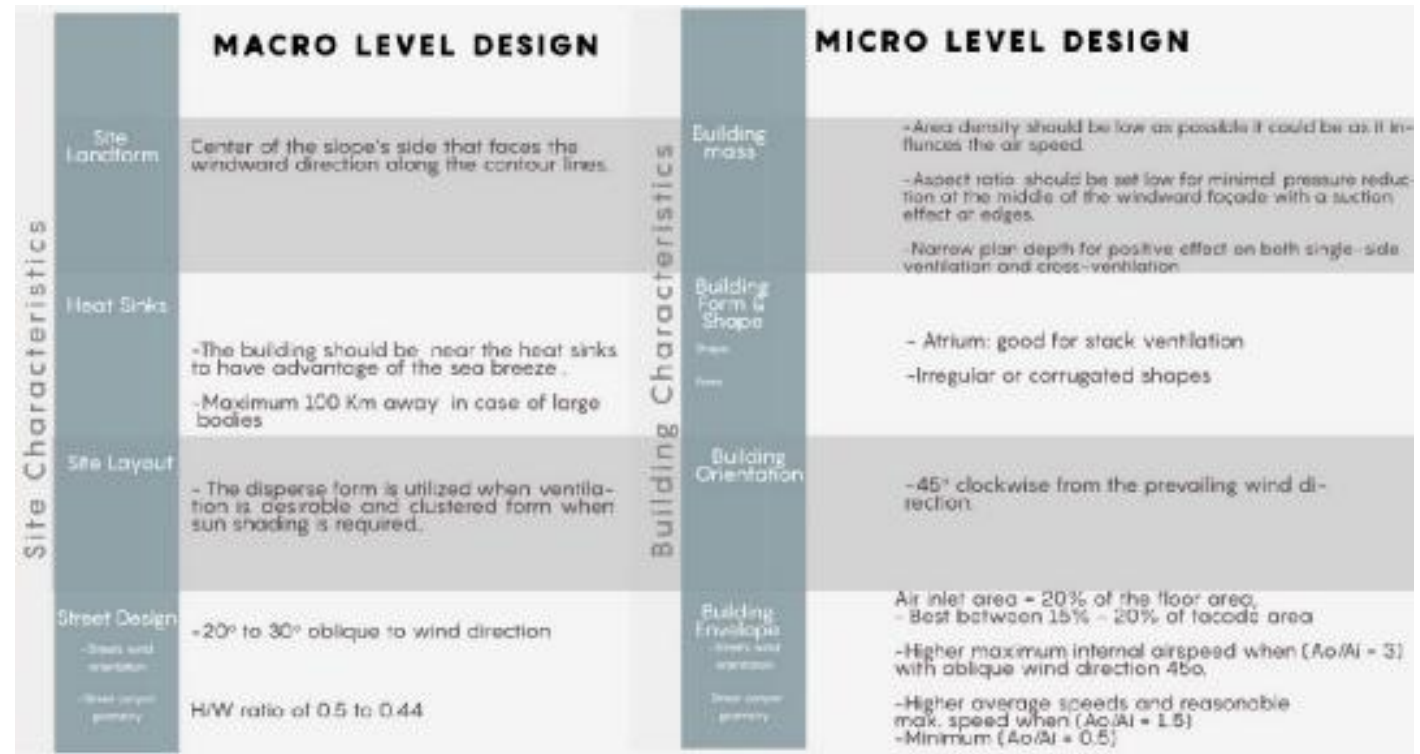

Figure 2 summary- technical guideline for macro and micro level design in moderate climate (researcher,2018)

\section{Project overview}

The Marin Country Day School new buildings were designed as new library tech labs, art studios and high-performance classrooms, and student services offices within an area of 23,094 square feet of new buildings and 10,646 square feet of renovations in California. The new 13,600 square feet building, which is the research center, reached the goal of net-zero energy in 2010 designed by EHDD (figure 3). MCDS Strategic plan seeks to offer ecological learning which is a vital part of its program, and to strengthen the students' sense of linking with nature on its unique site (AIA, 2010). Life at MCDS is integrated with nature; the whole campus is placed within its own watershed from the ridge of Ring Mountain to the San Francisco Bay, thus an exceptional opportunity for natural ventilation. Depending on temperature and wind speed, the building is designed to take benefit of the frequent breezes in a variety of ways (PG\&E, 2010).

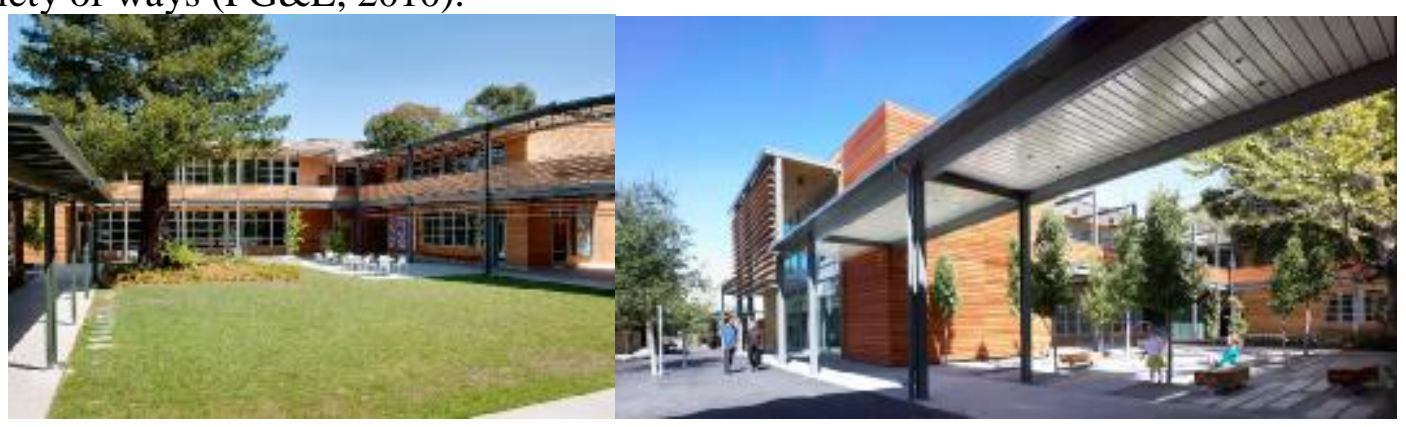

Figure 3 site plan and proposed blocks to be the base the analysis, (EHDD, 2017), edited by (researcher 2018). 
The research center contains 3 main blocks that will be the focus of the analysis (figure 4) it includes; library, art studios and classrooms. These are basically linked to outdoor learning spaces and suitable within the existing campus footprint and thus reserving natural surroundings. The outdoor space has a terraced Step-Up courtyard, that leads the landscape into the heart of the campus. Bioclimatic Design to support students' linking between inside and out, passive strategies were used in over 95 percent of spaces that depend on natural ventilation and daylight quality which boost the building to accelerate (AIA, 2010). Rainwater that falls on the roofs is gathered and preserved in an underground tank that feeds greywater to toilets and performances as a heat sink to cool the building. Intentionally placed overhangs shade the buildings, whereas considerate building orientation and operable windows permit the building to be naturally ventilated and passively cooled. On the roof, an evaporative cooling tower supports passive ventilation. All these natural systems are the result of careful engineering to provide exceptional comfort while maintaining connection to the outdoors (Goodwin, 2010).
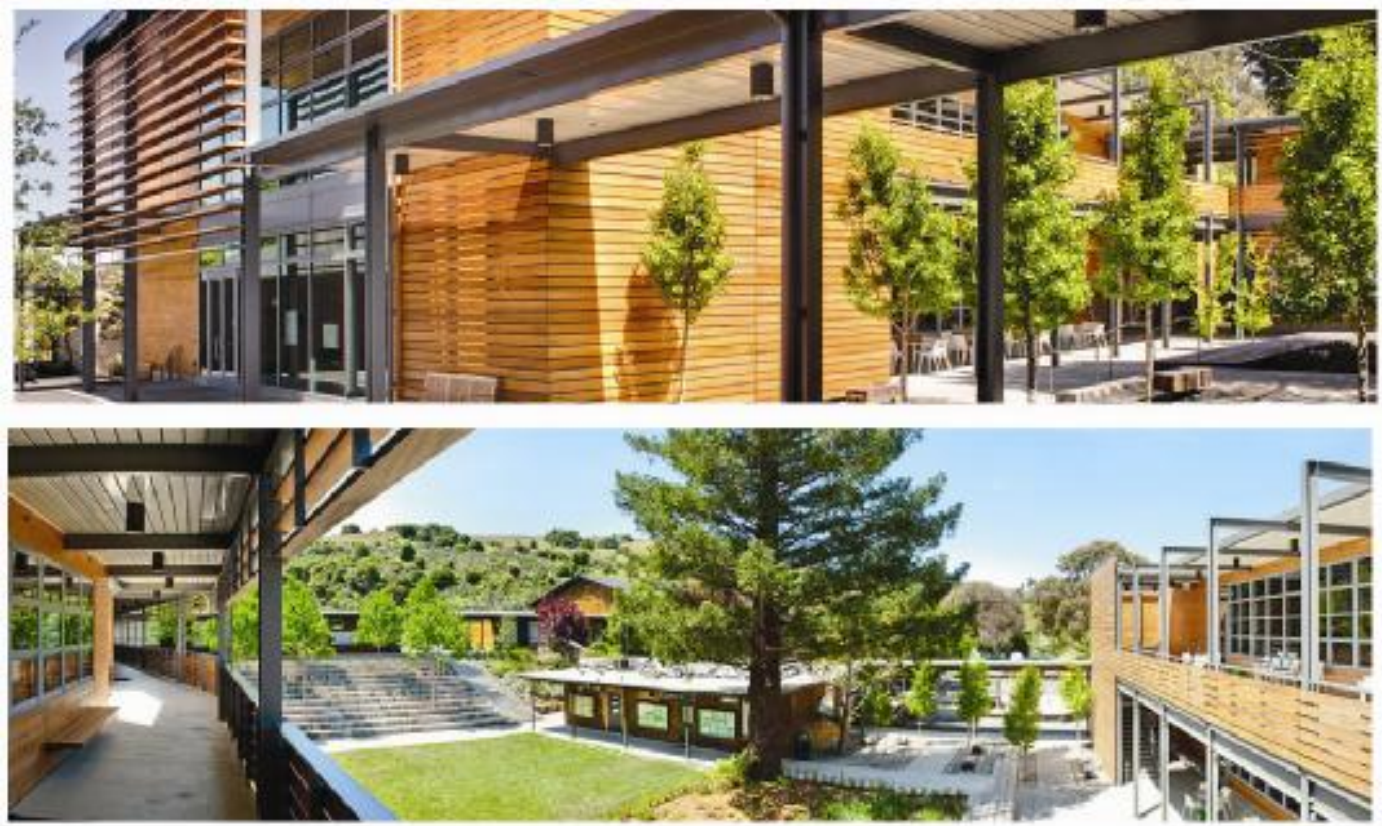

Figure 4 Marin Country Day School- new buildings views (EHDD, 2017)

\section{Theoretical Assessment}

To calculate natural ventilation in library, we assume the wind is $4 \mathrm{~m} / \mathrm{s}$ by applying the

Single sided ventilation could be calculated using Eqn1,2;

$\mathrm{Q}=0.025 * \mathrm{~A} * \mathrm{~V}$

Aw is the average opening area $=$ inlet window $2.3 * 15.4=37.5 \mathrm{~m} 2$

$\mathrm{v}$ is the air velocity $=4 \mathrm{~m} / \mathrm{s}$

Air change rate could be calculated using Eqn2;

$\times 3600 /$

$\mathrm{Q}=$ airflow $=4.05 \mathrm{~m} 3 / \mathrm{s}$

$\mathrm{V}=$ Volume $=417 \mathrm{~m} 3$

$\mathrm{ACH}=$ air change rate $=38$

To calculate natural ventilation in classrooms, we assume the wind is $4 \mathrm{~m} / \mathrm{s}$; by applying the single ventilation equation ,could be calculated using Eqn1,2;

$\mathrm{Q}=0.025 * \mathrm{~A} * \mathrm{~V}$

Aw is average opening area $=$ inlet window $2.5 * 6.3=16.38$

$\mathrm{v}$ is the air velocity $=4 \mathrm{~m} / \mathrm{s}$ 
Air change rate could be calculated using Eqn2;

$\mathrm{ACH}=\times 3600 /$

$\mathrm{Q}=$ airflow $=1.8 \mathrm{~m} / \mathrm{s}$

$\mathrm{V}=$ Volume $=162 \mathrm{~m}^{3}$

$\mathrm{ACH}=$ air change rate $=40$

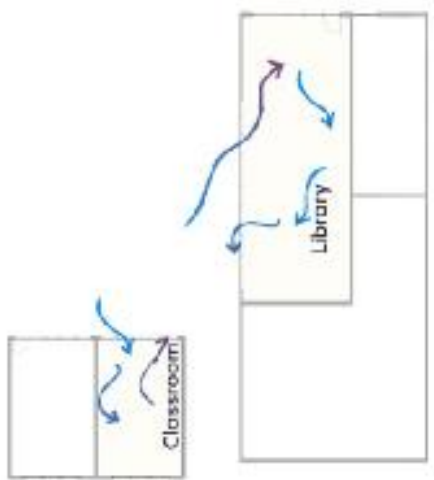

Figure 5 zones layout in cross ventilation (researcher 2018).

Library and classroom both achieved a successful comfortable indoor environment and good air quality with in ACh of 38 and 40 respectively.

\section{Architectural measure}

\section{Macro level design - Site characteristics}

Site landform and heat sinks

Site landform is flat with no vital difference in levels as seen in (figure 6). Heat sinks as bay of San Francisco Bay is found within an average radius of radius 1.0 $\mathrm{Km}$ thus the site is in the active zone of the sea breeze phenomena due to the pressure of heat sinks.

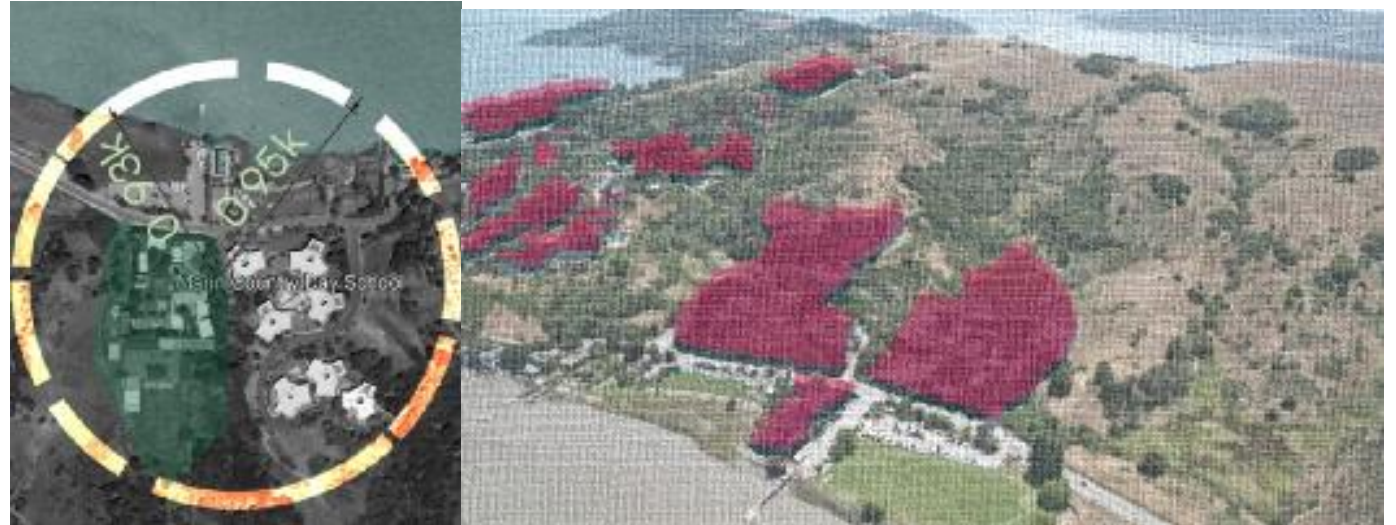

Figure 6 Left: Satellite image shows the site and san Francisco bay (google Earth,2015), edited by (researcher ,2017), Right: Site layout disperse urban form (EHDD, 2017), edited by (researcher 2018).

\section{Site Layout}

The urban fabric is planned as a disperse form consisting of low-rise detached buildings with wide spaces in between to make best use of the air movement. This allows wind access to more buildings for optimum ventilation.

Street design

There are no street canyons in the site street canyons are streets flanked by continuous lines of buildings. No urban configuration in the site.

Micro level design - Building characteristics

Building mass 
For block A

Low rise building with relatively narrow depth mass built on a site with low area density. This mass is characterized with dimensions of $\mathrm{L}=34 \mathrm{~m}, \mathrm{~W}=14 \mathrm{~m}$ and $\mathrm{H}=8 \mathrm{~m}$ (Figure 7) and an $\mathrm{L} / \mathrm{W}$ ratio of 2.37 .

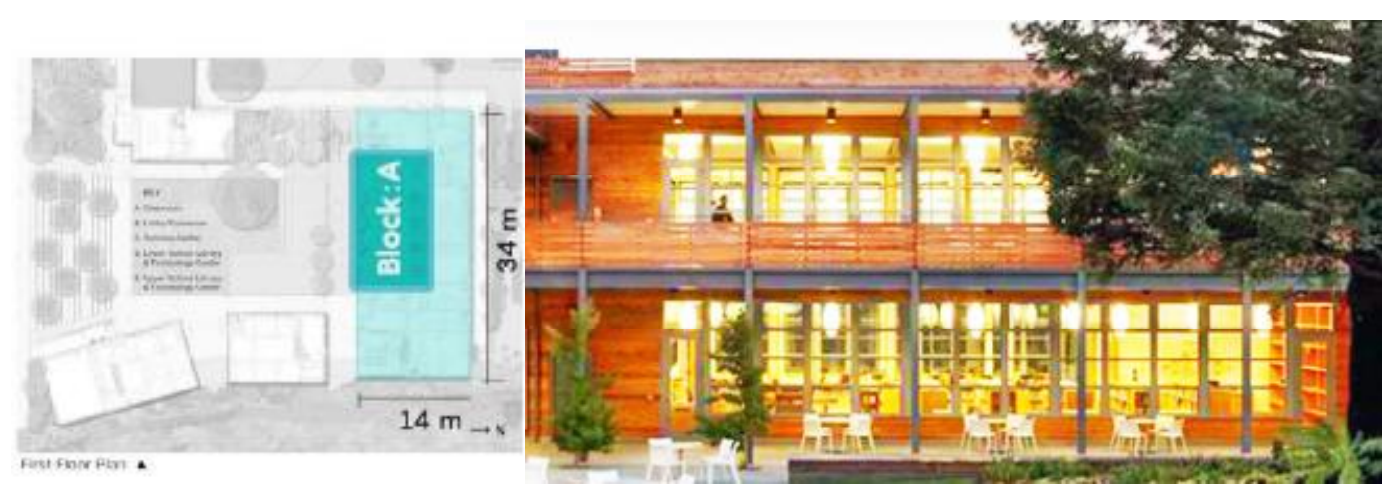

For block B

Figure 7 Block A: building mass dimensions (EHDD, 2017), edited by (researcher 2018).

Low rise building with relatively narrow depth mass built on a site with low area density. This mass is characterized with dimensions of $\mathrm{L}=12 \mathrm{~m}, \mathrm{~W}=9 \mathrm{~m}$ and $\mathrm{H}=8 \mathrm{~m}$ (Figure 8) and an $\mathrm{L} / \mathrm{W}$ ratio of 1.3 .

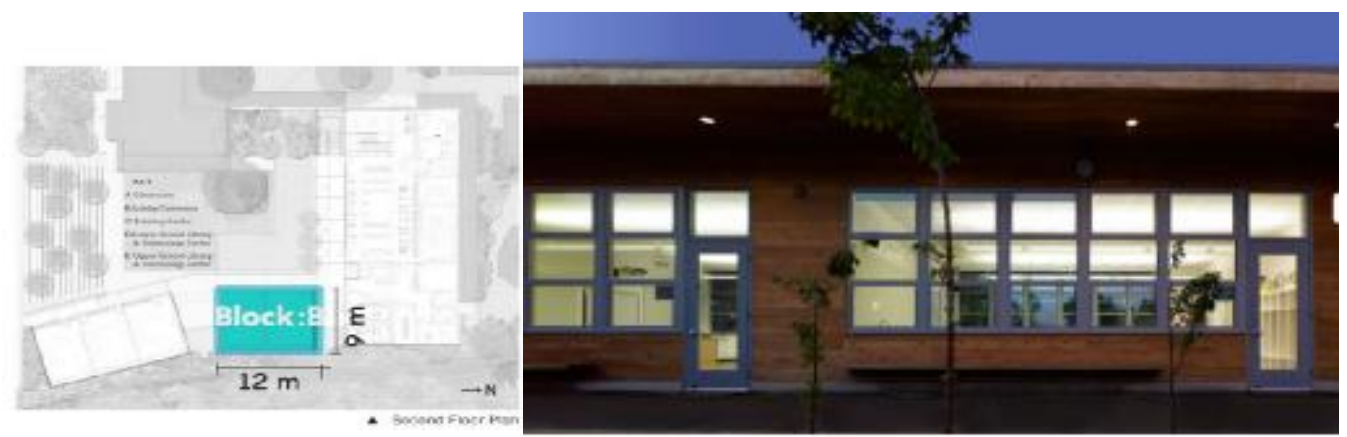

Figure 8 Block B: building mass dimensions (EHDD, 2017), edited by (researcher 2018).

Due to narrow plan for both blocks A and B, cross ventilation and single sided ventilation will have a good potential that will impact positively the air quality effect.

Building form and shape

Rectangular court yard form and block A and B both have a rectangular shape

Building orientation

Block A and B is oriented to the south-west direction with an angle of $45^{\circ}$ and $45^{\circ}$ respectively clockwise from the prevailing wind d irection (Figure 9)
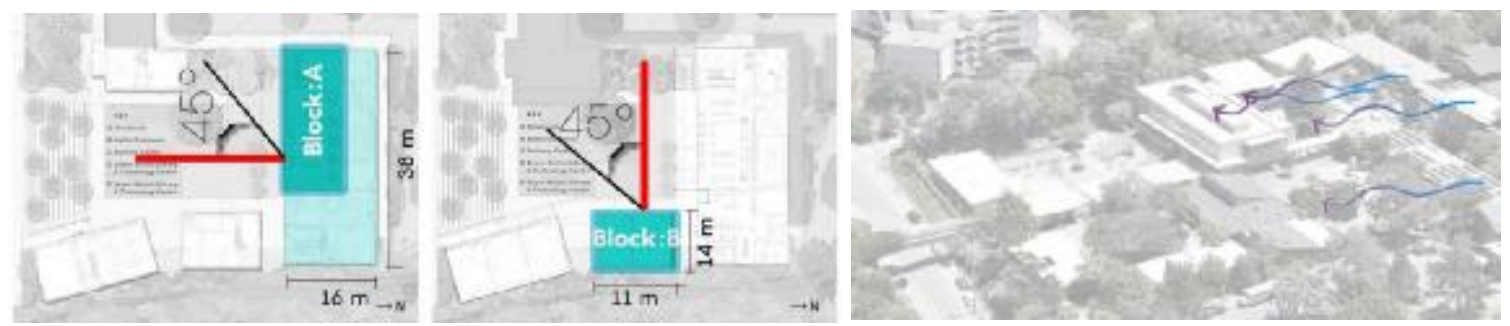

Figure 9 Blocks orientation in relation to wind direction (EHDD, 2017), edited by (researcher 2018).

Building Envelope

In block A total façade area openings are $23 \%$ of the total façade area $\left(302 \mathrm{~m}^{2}\right)$ and the openings area are $\left(70 \mathrm{~m}^{2}\right)$. Area of the inlet window over area of floor area was found to be 20 
$\%$ (area of the inlet window $2.3^{*} 15=37.5 \mathrm{~m} 2$ and area of the library $8.75^{*} 15.35=130 \mathrm{~m} 2$, $35 * 100 / 130=26.9 \%$ ).

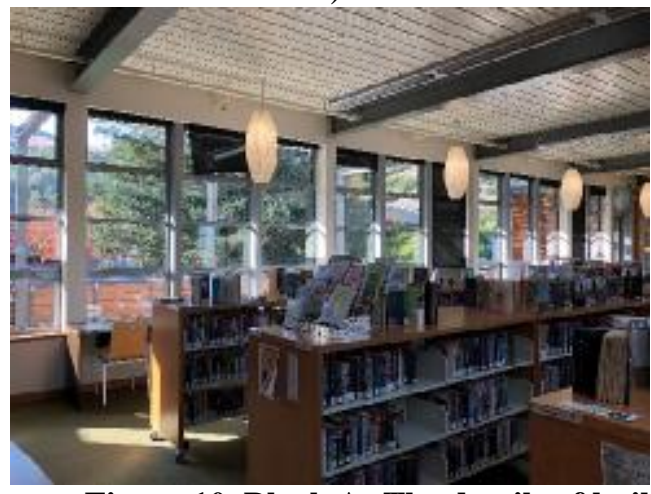

Figure 10 Block A: The details of building's openings and dimensions (EHDD, 2017), edited by (researcher 2018).

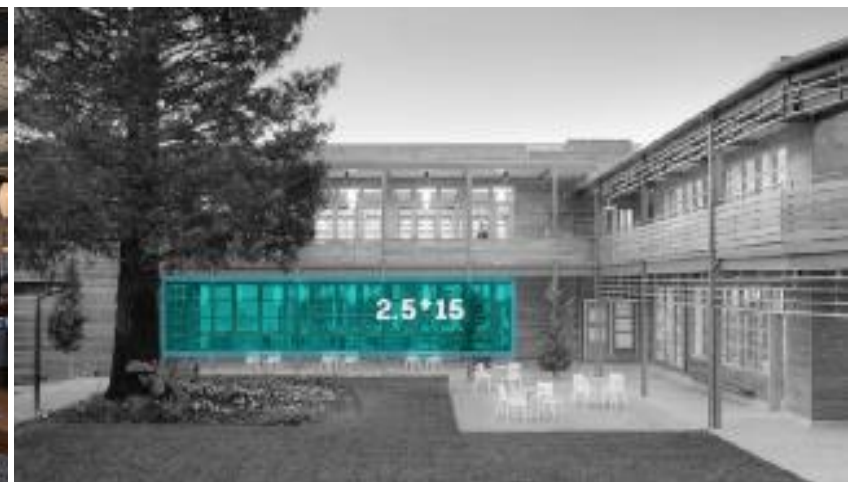

\section{In block B}

Total façade area openings are $57 \%$ of the total façade area $\left(98 \mathrm{~m}^{2}\right)$ and the openings $\left(56 \mathrm{~m}^{2}\right)$. Area of the inlet window over area of floor area was found to be $20 \%$ (area of the inlet window $6 * 2.5=15 \mathrm{~m} 2$ and area of the classroom $7 * 10=70 \mathrm{~m} 2,14 * 100 / 70=20 \%$ thus improves the cross ventilation).

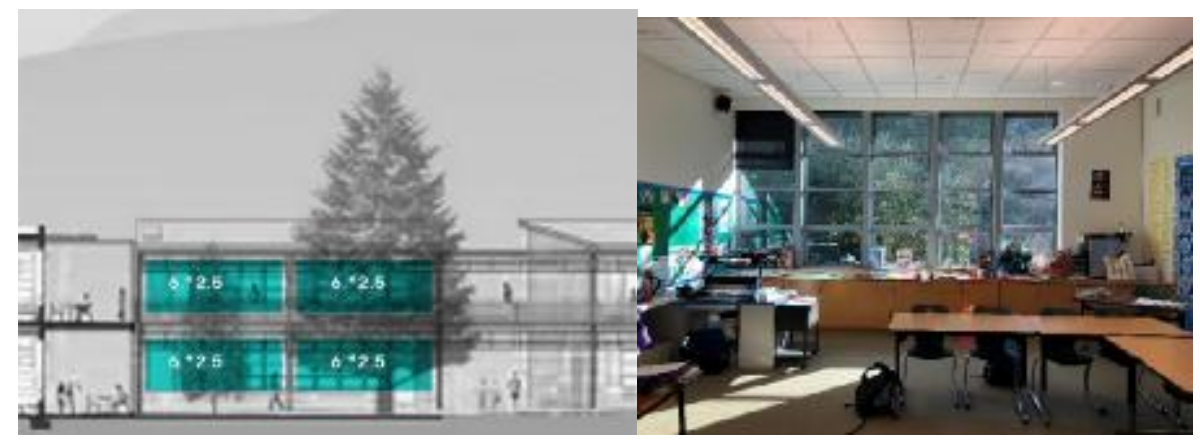

Figure 11 Block B: The details of building's openings and dimensions (EHDD, 2017), edited by (researcher 2018). 


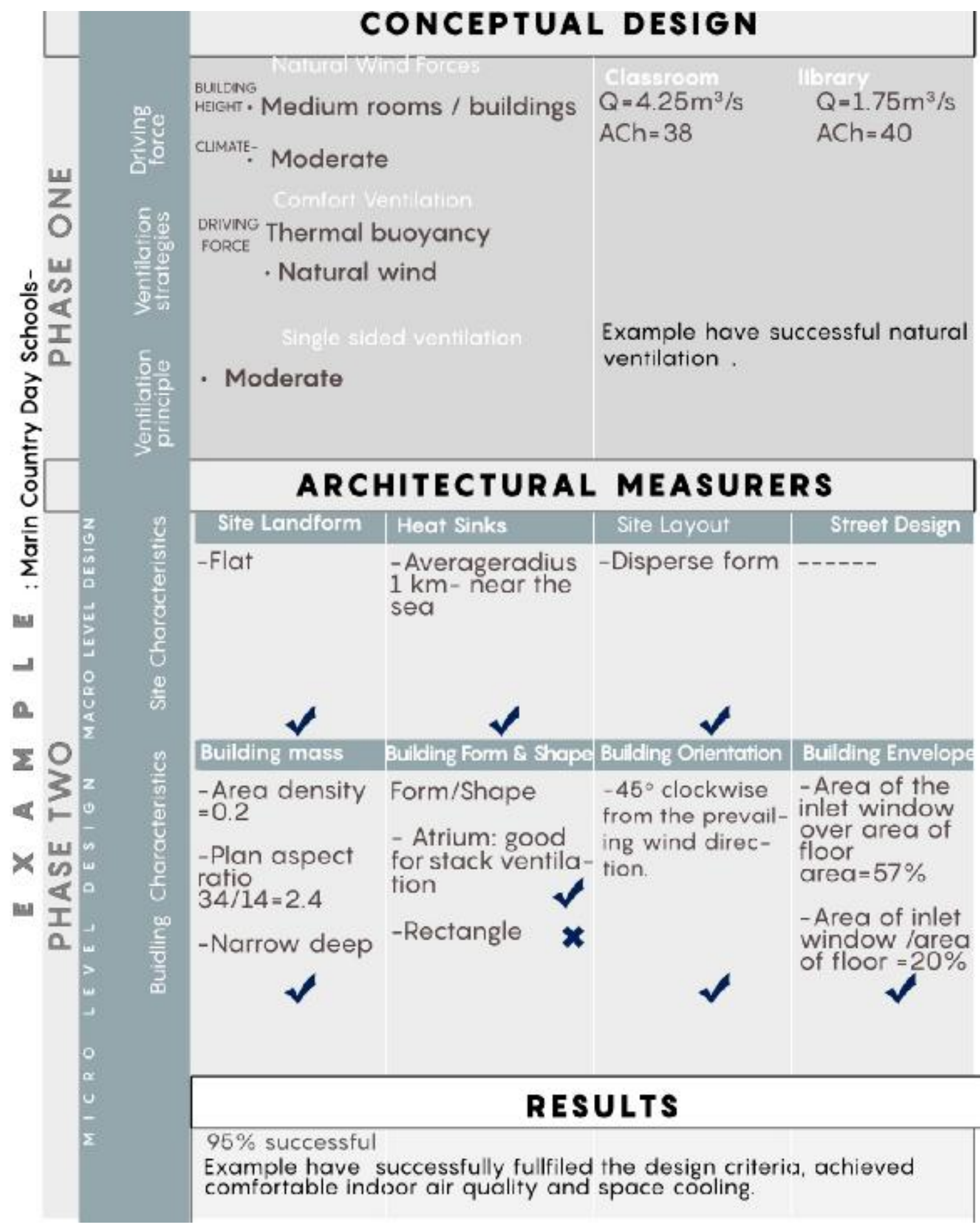

Figure 12summary for the example and natural ventilation design consideration (researcher 2018).

\section{CONCLUSION}

A significant factor in public development is education. A vast amount of time is spent in educational buildings. These buildings are assembled to shield the occupants against inadequate weather conditions and provide them with a healthy and tenable environment. Learning is an intense intellectual process that demands a substantial amount of physical and physiological effort therefore, these educational buildings require proper natural ventilation and acceptable quality of air flow. Otherwise, the inhabitant will be thermally dissatisfied and productively challenged. A key factor in producing healthy and comfortable indoor conditions is design, also good operation of the natural ventilation system is crucial. This paper focused on assessing natural ventilation design considerations and its effect on airflow and their 
association to thermal comfort in studios in educational buildings in Alexandria Egypt. This paper assesses successful international educational buildings; Marin Country Day School to verify the design criteria concluded from literature. By comparing the factors of the macro and micro level design in the example it was found that it achieved a successful satisfying comfortable healthy environment and fresh indoor air quality. It is found that the ventilation design criteria essentially influence the ventilation potential as well as the indoor air quality and thermal comfort in educational facilities.

\section{REFERENCES}

1. Aia. (2010). Marin Country Day School Learning Resource Center And Courtyard. Retrieved From Http://Www.Aiatopten.Org/Node/276

2. Architectural Review, Z. H. (1979). Architectural Review. V.165 N.988, 356. Retrieved From Http://Www.Rndrd.Com/N/1109

3. Bhatia, A. (2012). Hvac - Natural Ventilation Principles And Practices. Stony Point, Ny 10980: Continuing Education And Development, Inc. Retrieved From : Https://Www.Cedengineering.Com/Userfiles/Hvac\%20\%20natural\%20ventilation\%20principles\%20.Pdf.

4. Dekay, M. \& Brown, G. Z. (2014). Sun, Wind, And Light: Architectural Design Strategies. Canada: 3rd Edition Ed. John Wiley \& Sons.

5. Ehdd. (2017). Marin Country Day School. Retrieved From Http://Www.Ehdd.Com/Work/Marin-Country-Day-School

6. Francis Allard, Mat Santamouris. (2002). Natural Ventilation In Buildings: A Design Handbook.

7. Givoni, B. (1976). Passive Low Energy Cooling Of Buildings.

8. Gomaa, B. ( 2015). Natural Ventilation Potential For Residential Buildings In Alexandria. Egypt: S.L.: S.N.

9. Goodwin, A. (2010). Leed Platinum Marin Country Day School Is The First ZeroEnergy Classroom In North America. Retrieved From Http://Inhabitat.Com/LeedPlatinum-Marin-Country-Day-School-Is-The-First-Zero-Energy-Classroom-In-NorthAmerica/

10. Haddad, S. (2016). Thermal Comfort In Naturally Ventilated Schools :A Field Study Of Thermal Comfort In Iranian Primary School Classrooms. Faculty Of Built Environment The University Of New South Wales.

11. Heiselberg, P. (2004). Natural Ventilation Design. International Journal Of Ventilation, 2(4): P. 295-312.

12. Heiselberg, P. (2006). Design Of Natural And Hybrid Ventilation. , Aalborg University. (Dce Lecture Notes; No. 5: Aalborg: Department Of Civil Engineering.

13. Heiselberg, Per Kvols. (2006). Design Of Natural And Hybrid Ventilation. Denmark.

14. Kamoru, S. A. (2010). Effect Of Building Design For Natural Ventilation On The Comfortof Building Occupants In South-Western Nigeria. The Department Of Building Technology,Faculty Of Environmental Technology, The Polytechnic Ibadan,Ibadan, Oyo State.

15. Liu, Pei-Chun. (2012). A Modelling Study Of Segmentation Of Naturally Ventilated Tall Office Buildings In A Hot And Humid Climate. University Of Nottingham.

16. Ng, Edward. (2012). Planning Department: Urban Climatic Map And Standards For Wind Environment. Hongkong: - Feasibility Study, School Of Architecture, Cuhk.

17. Osman, M. M. (2011). Evaluating And Enhancing Design For Natural Ventilation In Walk-Up Public Housing Blocks In The Egyptian Desert Climatic Design Region. Scotland: Dundee School Of Architecture.

18. Pg\&E. (2010). Marin Country Day School - Pacific Gas And Electric Company. Retrieved From Pacific Energy Center, San Francisco, California : Www.Pge.Com/Pec/Daylight - 415-973-7206

19. T. Rashed And C. Jürgens Eds. (2010). Remote Sensing Of Urban And Suburban Areas. 3 Remote Sensing And Digital Image Processing 10, Doi 10.1007/978-1-40204385-7_2, (C) Springer Science+Business Media B.V.

20. Wu, Ziqi. (2011). Evaluation Of A Sustainable Hospital Design Based On Its Social And Environmental Outcomes. Usa: E Faculty Of The Graduate School. 